\title{
Pengembangan Media Teka-Teki Silang Biologi Berbasis Android Materi Sistem Gerak untuk Meningkatkan Keterampilan Berpikir Kreatif Siswa
}

\author{
Paula Yunita Seku Ra'o' ${ }^{1), a)^{*}}$, Yohanes Bare ${ }^{2), b)}$, Sukarman Hadi Jaya Putra ${ }^{3), c)}$ \\ ${ }^{1)}$ Pendidikan Biologi, FKIP, Universitas Nusa Nipa Indonesia \\ *Bareyohanes@gmail.com
}

Abstrak: Pendidikan merupakan faktor penting dalam kehidupan manusia, oleh karena itu perlu dilakukan inovasi dalam rangka peningkatan berpikir kreatif siswa. Salah satu kajian yang dilakukan adalah melakukan inovasi dalam media pembelajaran dengan menggunakan teka-teki silang (TTS). TTS diprediksi memiliki manfaat dalam rangka merangsang berpikir siswa, penelitian ini diintegrasikan dalam bentuk android sehingga dapat meningkatkan minat siswa. Tujuan penelitian ini mengembangan media teka-teki silang pada materi sistem gerak pada manusia berbasis android untuk memberdayakan keterampilan berpikir kreatif siswa. Penelitian ini dilaksanakan di SMA Negeri Wolojita, jenis penelitian pengembangan atau Research and Development (R\&D) yang menghasilkan sebuah media pembelajaran berbasis android dengan menggunakan model Borg and Gall. Hasil yang diperoleh adalah Media TTS Biologi Berbasis Android yang dikembangaka dinyatakan sangat valid dan sangat layak untuk diimplementasikan dalam pembelajaran Biologi khusus materi sistem gerak dalam meningkatkan berpikir kreatif siswa.

Kata Kunci: android, berpikir kreatif, sistem gerak, TTS.

\section{PENDAHULUAN}

Pendidikan merupakan salah satu faktor penting dalam kehidupan manusia. Pendidikan mendorong manusia agar dapat menggali potensi yang terdapat dalam dirinya, sehingga mampu menghadapi setiap perubahan yang terjadi akibat perkembangan ilmu pengetahuan dan teknologi. Dalam dunia pendidikan guru dan peserta didik dituntut untuk lebih kreatif, karena dengan kemampuan berpikir kreatif siswa mampu menyatukan sesuatu yang sudah ada menjadi sesuatu yang baru (S \& Bare, 2019). Berpikir kreatif merupakan suatu pemikiran yang berusaha menciptakan gagasan yang baru. Berpikir kreatif dapat juga diartikan sebagai suatu kegiatan mental yang digunakan seseorang untuk membangun ide atau gagasan yang baru. Berpikir kreatif mampu memunculkan potensi diri (bakat yang tersembunyi) dalam diri manusia, sehingga mampu dalam berbuat sesuatu. Pendidikan saat ini memasuki era dunia media, dimana kegiatan pembelajaran menggunakan media sebagai perantara guru dalam proses pembelajaran di kelas. Media (singular medium) yang merujuk pada sesuatu yang dapat menghubungkan informasi antara sumber dan penerima informasi.

Menurut Wulan et al., (2019) media adalah berbagai jenis komponen dalam lingkungan siswa yang dapat merangsangnya untuk belajar. Dengan adanya media pembelajaran, siswa akan terbantu dalam pemahaman materi yang diajarkan oleh guru pada setiap pertemuan. Serta dengan tersedianya media pembelajaran tenaga pendidik dapat menciptakan situasi kelas yang kondusif. Pembelajaran dalam bidang biologi adalah kolaborasi antara pengetahuan teori dan praktik, peningkatan pemahaman materi biologi dapat dilakukan dengan memberikan inovasi selama proses pembelajaran. Salah satu pengembangan berupa penggunaan media pembelajaran. Penggunaan media dalam pembelajaran biologi juga harus bervariasi dan disesuaikan dengan materi yang disampaikan, sehingga guru perlu memilih media yang akan digunakan pada proses pembelajaran. Guru juga harus memiliki kemampuan untuk mengintegrasikan media pembelajaran kedalam rencana pembelajaran (Pada et al., 2021). Media pembelajaran ini dapat membantu guru untuk memberikan pengalaman belajar yang berbeda dan bervariasi, lebih mudah dimengerti, lebih menarik, menyenangkan, serta dapat memberi motivasi belajar pada peserta didik (Ade et al., 2021; Bare et al., 2021; Sizi et al., 2021). 
Pada kenyataannya penggunaan media di sekolah-sekolah masih belum optimal, banyak guru yang menggunakan metode ceramah dalam pembelajaran sehingga antusias siswa dalam proses belajar itu sangat kurang. Hal ini sejalan pada hasil observasi dan wawancara dengan salah seorang guru biologi di SMA Negeri Wolojita, diperoleh informasi bahwa media pembelajaran yang digunakan dalam proses pembelajaran selama ini masih menggunakan metode ceramah, media berupa buku cetak dan Lembar kerja Siswa (LKS). Sedangkan pada materi sistem gerak pada manusia, guru menggunakan media tambahan seperti media gambar. Akan tetapi media tersebut sangat terbatas sehingga membuat siswa kurang antusias dalam belajar. Observasi juga dilakukan dengan beberapa peserta didik kelas XI MIA di sekolah SMA Negeri Wolojita. Mereka menyatakan bahwa, guru kurang menggunakan media pembelajaran pada materi sistem gerak pada manusia. Hal ini dikarenakan media yang digunakan terbatas dan kurangnya kreatifitas seorang guru dalam membuat atau menentukan media yang seharusnya digunakan (Bare \& Sari, 2021; Dawa et al., 2021). Media pembelajaran teka-teki silang juga belum pernah diterapkan di sekolah tersebut. Sehingga pembelajaran yang selama ini diterapkan oleh guru cenderung membosankan, keinginan siswa untuk menggunakan media yang menarik dan menyenangkan cukup tinggi. Salah satu upaya yang digunakan dalam mengatasi masalah yang dihadapi siswa adalah melakukan perubahan dalam proses pembelajaran, salah satunya dengan menggunakan media pembelajaran yang lebih menarik minat siswa dalam proses pembelajaran. Terdapat berbagai macam media pembelajaran salah satunya adalah media teka-teki silang (crossword puzzle). Menurut Ade dkk, (2021) teka-teki silang menjadi salah satu media dalam pembelajaran biologi dan hasil penelitian yang dilakukan bahwa media TTS sangat valid dan layak digunakan. Teka-teki silang (crossword puzzle) termasuk dalam jenis permainan yang dapat mengasah otak. Teka-teki silang (crossword puzzle) merupakan suatu pendekatan yang dikemas dalam bentuk permainan sehingga dapat merangsang daya pikir peserta didik dalam proses pembelajaran (Ade et al., 2021).

Sistem gerak merupakan materi dalam mata pelajaran Biologi yang dipelajari di kelas XI semester ganjil dalam kurikulum 2013. Materi sistem gerak merupakan salah satu materi biologi yang membahas materi tentang nama-nama rangka, macam-macam otot dan persendian, kelainan dan gangguan pada sistem gerak. Materi sistem gerak sebenarnya bukan materi yang tergolong sulit hanya saja merupakan materi yang berkarakteristik teori dan banyak hafalan, sehingga siswa dituntut untuk memiliki daya ingat dan kemampuan menghafal yang tinggi karena materinya berisi hafalan, siswa menjadi kurang tertarik untuk mempelajarinya. Padahal materi sistem gerak sangat erat dengan kehidupan sehari-hari, sehingga pemahaman terhadap materi ini sangat penting. Tujuan penelitian ini mengembangan media teka-teki silang pada materi sistem gerak pada manusia berbasis android untuk memberdayakan keterampilan berpikir kreatif siswa.

\section{METODE}

\section{Waktu dan Tempat Penelitian}

Penelitian ini dilaksanakan pada bulan oktober 2021 sampai dengan bulan November 2021 semester ganjil tahun ajaran baru 2021/2022 dan bertempat di SMA Negeri Wolojita yang beralamat di Kecamatan Wolojita, Kabupaten Ende.

\section{Model Pengembangan}

Penelitian ini tergolong jenis penelitian pengembangan atau Research and Development (R\&D) yang menghasilkan sebuah media pembelajaran berbasis android dengan menggunakan model Borg and Gall (Borg \& Gall, 2003). Menurut Borg and Gall yang dimaksud dengan model penelitian pengembangan (R\&D) adalah penelitian pengembangan sebagai usaha untuk mengembangkan dan memvalidasi produk-produk yang digunakan dalam proses pembelajaran (Elci et al., 2021). Langkah Penelitian Pengembangan (R\&D)Menurut Borg and Gall Potensi Masalah, Pengumpulan Data, Desain Produk, Uji Coba Produk Tahap I. Analisis dan Revisi Produk Tahap I, Uji Coba Produk Tahap II, Analisis dan Revisi Produk Tahap II, Uji Coba Produk Tahap III, dan Analisis dan Revisi Produk Akhir.

Teknik pengumpulan data yang digunakan, untuk mendapatkan data yang akurat adalah, angket/kuesioner wawancara, observasi lapangan, dan dokumentasi. 


\section{Analisis Data}

Setelah data terkumpul kemudian dilakukan analisis. Metode analisis yang digunakan dalam penelitian ini adalah:

\section{Analisis Validasi}

Analisis validasi merupakan analisis yang digunakan untuk menganalisis valid dan tidaknya suatu produk. Analisis validasi penelitian dapat dihitung dengan rumus persentase validasi (Tabel 1) (Rufa dkk, 2014).

Tabel 1. Kriteria Kevalidan Media Teka-Teki Silang Biologi Berbasis Android

\begin{tabular}{ccc}
\hline No & Kriteria & Kategori \\
\hline 1 & $85,01 \%-100 \%$ & Sangat Valid \\
2 & $70,01 \%-85,00 \%$ & Valid \\
3 & $50,01 \%-70,00 \%$ & Cukup Valid \\
4 & $01,00 \%-50,00 \%$ & TidakValid \\
\hline
\end{tabular}

2. Analisis Angket Tanggapan Guru dan Siswa Setelah Dilakukan Uji Coba Produk

Angket tanggapan digunakkan untuk mengumpulkan data mengenai tanggapan guru dan siswa terhadap media teka-teki silang biologi yang dikembangkan. Angket tanggapan berisi pertanyaan dengan jawaban semi terbuka. Urutan penulisannya adalah judul, pernyataan dari peneliti, identitas responden, petunjuk pengisian, dan item pertanyaan. Analisis angket kelayakan pada penelitian ini dapat kita ketahui melalui penilaian skala likert (Fourwantono, 2017).

Tabel 2. Tabulasi Data Skala Likert

\begin{tabular}{cc}
\hline Skala Penilaian & Skor \\
\hline Sangat Setuju & 4 \\
Setuju & 3 \\
Tidak Setuju & 2 \\
Sangat Tidak Setuju & 1 \\
\hline
\end{tabular}

Angket tanggapan bersifat kuantitatif data dapat diolah secara penyajian presentasi dengan menggunakan skala likert sebagai skala pengukuran. Skala ini disusun dalam bentuk suatu pernyataan dan diikuti dengan empat tanggapan. Untuk keperluan analisis kuantitatif, maka jawaban itu dapat diberi skor (Tabel 2). Selanjutnya data intervalnya dapat dianalisis dengan menghitung persentase jawaban berdasarkan scoring setiap jawaban. (Tabel 3).

Tabel 3. Kriteria Kelayakan

\begin{tabular}{ccc}
\hline No & Skor rata-rata & Kategori \\
\hline 1 & $0 \%-25 \%$ & Tidak Layak \\
2 & $26 \%-50 \%$ & KurangLayak \\
3 & $51 \%-75 \%$ & Layak \\
4 & $76 \%-100 \%$ & Sangat Layak \\
\hline
\end{tabular}

Pengembangan media teka-teki silang biologi untuk memberdayakan keterampilan berpikir kreatif siswa SMA dinyatakan layak secara teoritis apabila persentase kelayakannya adalah lebih dari 51\%.

\section{HASIL DAN PEMBAHASAN}

Penelitian ini bertujuan untuk menghasilkan media pembelajaran TTS Biologi pada materi sistem gerak pada manusia untuk peserta didik kelas XI SMA. TTS Biologi dinyatakan valid dan layak berdasarkan hasil validasi dari validator praktisi serta hasil uji coba lapangan. Penelitian pengembangan ini mengacu pada model pengembangan Borg \& Gall, yang dibatasi pada beberapa tahap, antara lain: potensi masalah, pengumpulan data, tahap desain produk, uji coba produk tahap I, revisi produk tahap I, uji coba produk tahap II, revisi produk tahap II, uji coba produk tahap III, analisis dan revisi produk akhir. 


\section{Potensi Masalah}

Berdasarkan hasil studi pendahuluan, observasi dan wawancara guru dan peserta didik, pokok permasalahan yang ditemukan pada penelitian yaitu penggunaan media yang kurang berinovasi dalam mempelajari materi sistem gerak pada manusia sehingga pembelajaran biologi terkesan membosankan dan sulit dipahami. Dengan demikian pengembangan media pembelajaran teka-teki silang biologi dianggap memiliki potensi untuk mengatasi permasalahan tersebut.

\section{Pengumpulan Data}

Pengumpulan data bersumber dari beberapa referensi, yakni buku biologi untuk siswa SMA/MA kelas XI peminatan matematika dan ilmu-ilmu alam, buku praktis belajar biologi kelas XI SMA/MA program ilmu pengetahuan alam, silabus dan RPP mata pelajaran biologi materi sistem gerak pada manusia, pembuatan soal teka-teki silang ini menggunakan indikator berpikir kreatif. Hal ini bertujuan untuk memberdayakan berpikir kreatif siswa.

\section{Desain Produk}

Tahap ini merupakan tahap pendesainan produk TTS, dengan desain kotak-kotak TTS menggunakan aplikasi Eclipse Crossword Puzzle. Media TTS ini disertakan dengan buku panduan yang berisi materi dan petunjuk penggunaan media TTS sehingga dapat memicu siswa untuk berpikir kreatif. Desain TTS biologi dalam bentuk buku dengan menggunakan ms publisher. Langkah-langkah yang dilakukan pada tahap ini yaitu:

a. Pemilihan judul

TTS yang dikembangkan diberi judul "Teka-Teki Silang Biologi Materi Sistem Gerak Pada Manusia untuk SMA Kelas X"

b. Halaman Sampul (Cover)

Cover merupakan halaman dari sebuah TTS Biologi yang terdiri atas cover depan dan belakang. Cover depan berisikan judul TTS, gambar ilustrasi biologi, dan nama penulis. Pada cover belakang berisikan judul TTS, rangkuman TTS dan logo UNIPA (Gambar 1).
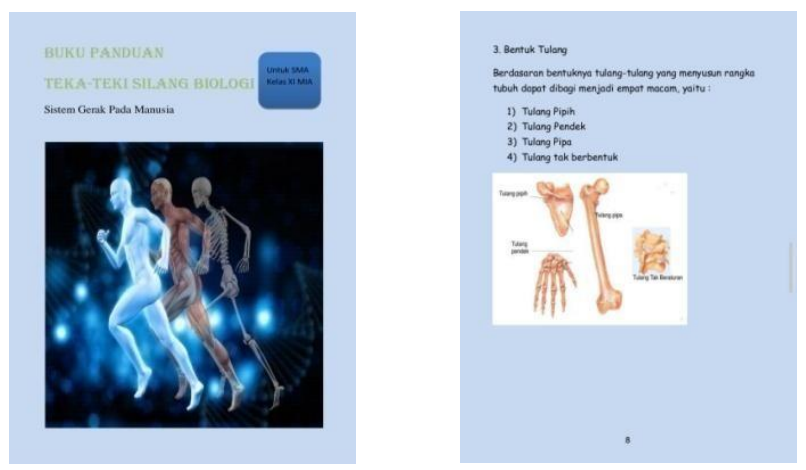

Gambar 1. Tampilan Cover Depan dan Belakang TTS Biologi

c. Kata Pengantar

Kata pengantar dalam TTS ini berisikan gambar singkat pengantar pembelajaraan dan ucapan terima kasih penulis.

d. Daftar Isi

Bagian ini menginformasikan kepada pengguna tentang topik-topik yang ditampilkan dalam TTS Biologi sesuai urutan dan nomor halaman.Dengan demikian, pembaca lebih mudah untuk menemukan setiap kegiatan tanpa harus membuka setiap halaman.

e. Kompetensi Inti

Kompetensi inti merupakan gambaran mengenai kompetensi utama yang harus dikuasai oleh peserta didik dalam aspek sikap (afektif), aspek pengetahuan (kognitif), dan aspek keterampilan (psikomotorik) untuk setiap jenjang, kelas dan mata pelajaran (Gambar 2). 


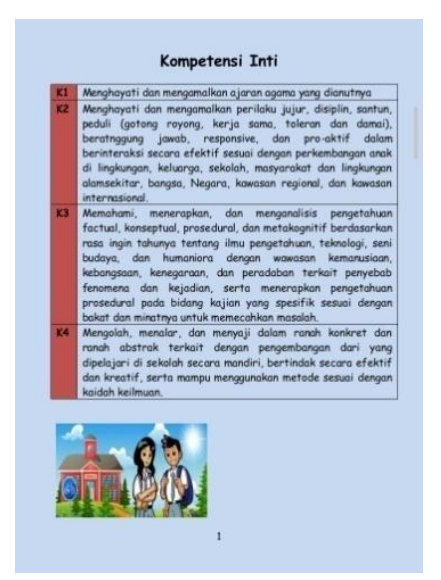

Gambar 2. Tampilan Kompetensi Inti

f. Kompetensi Dasar dan Indikator Pencapaian Kompetensi

Kompetensi dasar dibuat dengan tujuan untuk mencapai kompetensi inti dalam pembelajaran, sedangkan indikator pencapaian kompetensi dibuat sebagai tolak ukur dalam ketercapaian suatu KD. Tampilan KD dan indikator pencapain kompetensi mencakup isi KD dan IPK (Gambar 2).

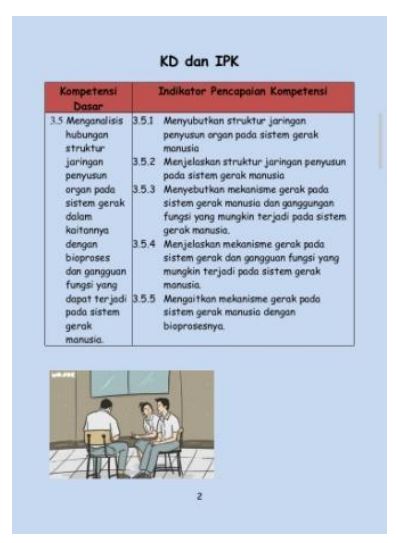

Gambar 2. Tampilan KD dan Indikator Pencapaian Kompetensi

g. Tujuan Pembelajaran

Tujuan pembelajaran merupakan gambaran, proses dan hasil belajar oleh peserta didik dalam mencapai standar kelulusan kompetensi (Gambar 3).

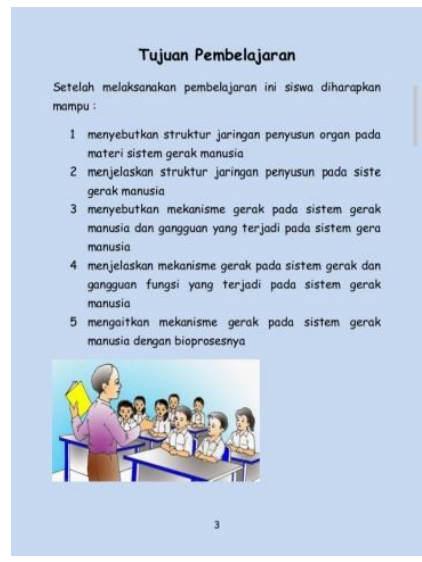

Gambar 3. Tampilan Tujuan Pembelajaran

h. Peta Konsep

Peta konsep merupakan gambaran hubungan antar sub materi sistem gerak pada manusia dalam TTS Biologi (Gambar 4). 


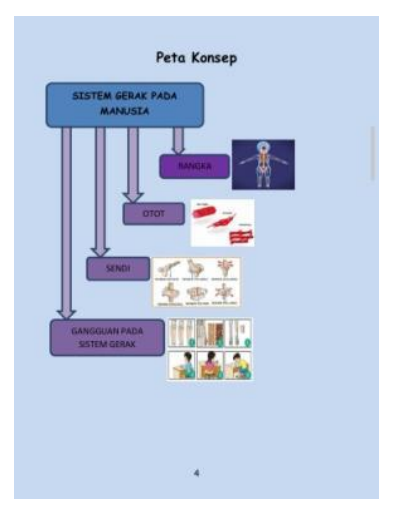

Gambar 4. Tampilan Peta Konsep

i. Info Biologi

Merupakan informasi yang berkaitan dengan materi sistem gerak.Info biologi disusun untuk menambah pengetahuan peserta didik (Gambar 5).
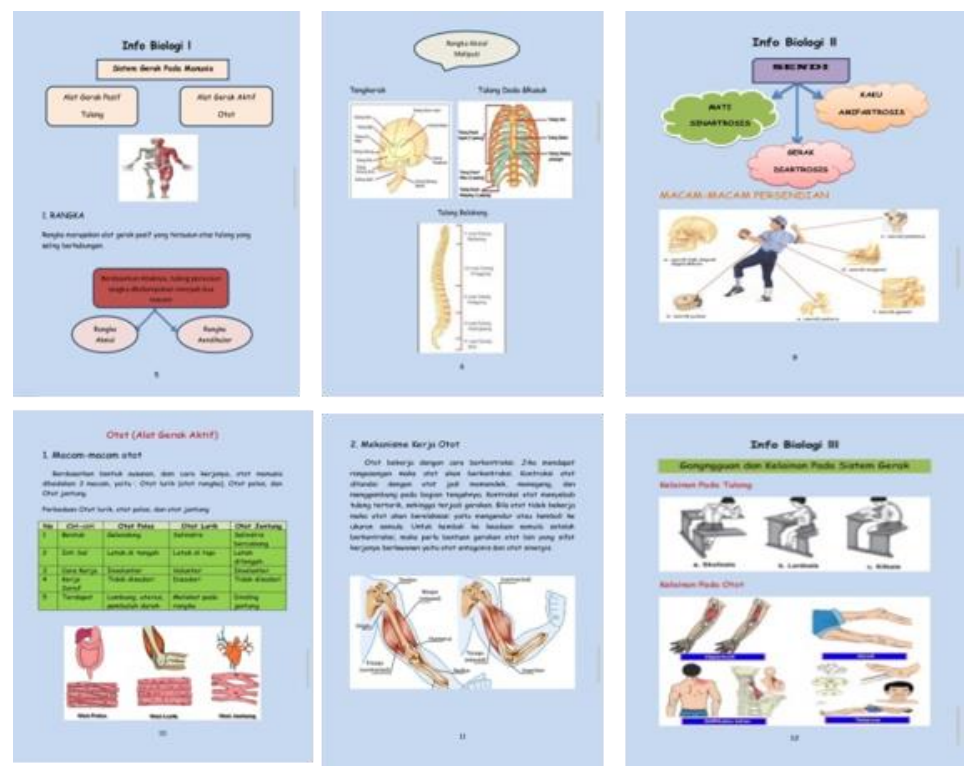

Gambar 5. Tampilan Info Biologi

Pada info biologi dibagi menjadi 3 yaitu info biologi 1 yang membahas tentang Tulang berdasarkan letaknya, jenis tulang, dan bentuk tulang. Pada info biologi 2 membahas tentang hubungan antar tulang (persendian), macam-macam otot, dan mekanisme kerja otot.Pada info biologi 3 membahas materi kelainan dan gangguan pada sistem gerak.Pada ketiga info biologi ini juga terdapat gambar-gambar sebagai pendukung materi sistem gerak.

j. Petunjuk Penggunaan TTS

Petunjuk penggunaan TTS ini sebagai gambaran cara menggunakan TTS sehingga pengguna lebih mudah memahami perintah dan pengisian TTS (Gambar 6).

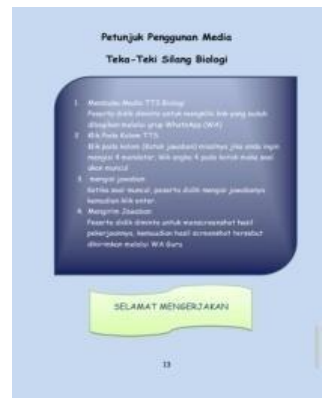

Gambar 6. Tampilan Penggunaan TTS 
k. Soal TTS Berbasis Android

TTS Biologi memuat soal-soal yang akan dikerjakan untuk melatih kemampuan peserta didik terhadap materi sistem gerak di setiap pertemuan (Gambar 7).

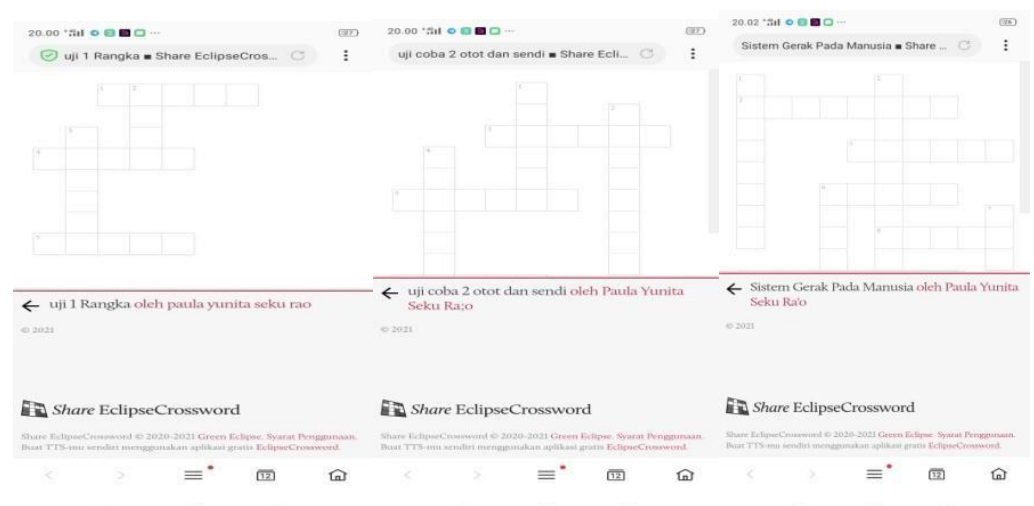

Gambar 7. Tampilan TTS Biologi 1,2, dan 3

Pada TTS ini dibagi menjadi 3 bagian yaitu latihan 1 memuat soal-soal yang berkaitan dengan tulang dan latihan 2 terdapat soal-soal yang berkaitan dengan sendi dan otot sedangkan pada latihan 3 memuat soal-soal yang berhubungan dengan sistem gerak pada manusia.

1. Daftar Pustaka

Daftar pustaka merupakan kutipan semua sumber yang digunakan dalam penulisan TTS Biologi.

m. Biodata penulis

Biodata penulis memuat tentang gambaran singkat riwayat penulis (Gambar 8).

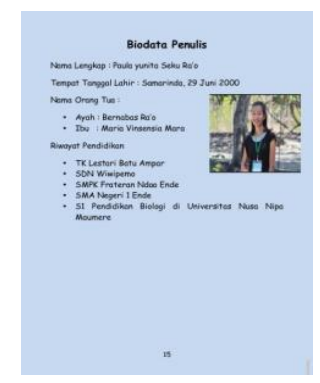

Gambar 8. Tampilan Biodata Penulis

Desain produk mencakup pengujian validitas produk TTS Biologi. Berdasarkan hasil validasi oleh validator terdapat beberapa saran dan masukan terhadap produk TTS Biologi. Perubahan TTS biologi dilakukan berdasarkan komentar atau saran para validator.

\section{Hasil Analisis Data}

1. Validasi Media Teka-Teki Silang Biologi Berbasis Android

Validasi diberikan kepada masing-masing validator yakni validator materi, media, bahasa dengan jumlah indikator penilaian yang berbeda. Beberapa aspek penilaian yakni aspek kelayakan materi dan aspek penyajian materi (validator materi), aspek bahasa (validator bahasa), aspek media (validator media). Penelitian Ndia et al., (2021) menyatakan bahwa nilai kevalidan produk berpengaruh terhadap implementasi produk di uji skala kecil maupun skala besar.

Tabel 4. Hasil Validasi Media Teka-Teki Silang Biologi Berbasis Android

\begin{tabular}{cccc}
\hline No & Validator & Data Hasil Validasi (\%) & Tingkat Validitas \\
\hline 1 & Ahli Materi & 94,2 & Sangat Valid \\
2 & Ahli Bahasa & 100 & Sangat Valid \\
3 & Ahli Media & 93,75 & Sangat Valid \\
\hline
\end{tabular}


Ahli materi menilai tentang isi materi sistem gerak pada manusia. Ahli materi yang menjadi validator dalam penelitian ini adalah guru biologi di SMA MAS AL-MUTTAQIN Wolowaru. Data diperoleh dengan memberikan angket diperoleh persentase 94,2\% dengan kriteria sangat valid (Tabel 4). Validasi ahli bahasa dilakukan untuk mengisi lembar angket penilaian pada media TTS. Pada angket penilaian ahli bahasa menilai tentang penyajian bahasa yang digunakan dalam media TTS biologi. Ahli bahasa yang menjadi validator dalam penelitian ini adalah seorang guru bahasa indonesia di SMA Negeri Wolojita. Data diperoleh dengan memberikan angket yang terdiri dari 1 aspek 4 pernyataan. Pada tabulasi uji ahli bahasa didapat persentase 93,75\% dengan kriteria sangat valid. Dengan demikian media TTS biologi yang disajikan sangat layak untuk digunakan di sekolah tersebut. Ahli media menilai tentang media TTS biologi yang digunakan dalam pembelajaran. Ahli media yang menjadi validator dalam penelitian ini adalah Oktavia Rona, Amd.Kom. Data diperoleh dengan memberikan angket. Ahli media kemudian penilaian komentar dan saran terhadap media yang digunakan. Pada tabulasi uji media didapat persentase $100 \%$ dengan kriteria sangat valid (Tabel 4).

\section{Analisis Data Angket Kelayakan}

Analisis data angket kelayakan mencakup angket kelayakan TTS biologi oleh peserta didik dan guru pada uji coba tahap I, II, III.

Tabel 5. Kelayakan Media Teka-Teki Silang Biologi Berbasis Android

\begin{tabular}{cccccc}
\hline No & Uji Coba Produk & Guru & Kriteria & Siswa & Kriteria \\
\hline 1 & Uji Coba 1 & 84,21 & Sangat Layak & 97,39 & Sangat Layak \\
2 & Uji Coba 2 & 89,47 & Sangat Layak & 98,17 & Sangat Layak \\
3 & Uji Coba 3 & 92,10 & Sangat Layak & 99,5 & Sangat Layak \\
\hline
\end{tabular}

Kategori produk hasil penilaian kelayakan TTS oleh guru mengacu pada kategori kelayakan (Tabel 5). Hasil analisis kelayakan TTS Biologi materi sistem gerak pada manusia berdasarkan penilaian oleh guru biologi pada masing-masing uji coba tahap I, uji coba tahap II, uji coba tahap III diperoleh persentase sebesar $84,2 \% ; 87,5 \% ; 87,5 \%$. Dengan demikian dapat dikatakan bahwa produk TTS biologi pada uji coba tahap I, II, III tergolong baik dan sangat baik digunakan dalam pembelajaran. Peningkatan skor dari uji coba tahap I, II, dan III (Tabel 5), hal ini dikarenakan adanya revisi berdasarkan kritik/saran dari guru kimia. Perubahan revisi yakni pada aspek kelayakan dan penyajian materi, aspek bahasa, dan aspek media. Berdasarkan penilaian, diperoleh hasil dengan hasil rerata persentase pada uji coba tahap I, II, III sebesa 97,39\%; 98,17\% dan 99,50\% (Tabel 5). Dengan demikian dapat dikatakan bahwa produk TTS biologi tergolong sangat baik sehingga layak digunakan. Adanya peningkatan persentase dikarenakan revisi pada aspek materi, aspek penyajian, aspek kebahasaan, aspek kegrafikan. Berdasarkan kritik dan saran peserta didik dan bertambahnya jumlah peserta didik pada setiap uji coba produk sehingga diperoleh banyak masukan untuk penyempurnaan produk.

Media pembelajaran TTS biologi memiliki nilai kevalidan yang sangat tinggi disertai nilai kelayakan yang tinggi, dengan demikian, secara umum produk TTS biologi materi sistem gerak pada manusia layak digunakan pada pembelajaran biologi dengan kategori kelayakan sangat baik. Kondisi ini juga didukung oleh penelitian yang dilakukan Purwantono, (2017) tentang pengembangan media teka-teki silang biologi untuk memberdayakan keterampilan berpikir kreatif peserta didik SMP dengan menggunakan penelitian research and development. Hasil penelitian menunjukan bahwa media pembelajaran sangat valid menurut pakar dengan persentase $94,44 \%$. Hasil penelitian ini dengan didukung oleh beberapa rujukan penelitian, menunjukan bahwa TTS biologi sangat dibutuhkan sebagai media pembelajaran dalam meningkatkan kemampuan berpikir kreatif materi biologi khususnya sistem gerak pada manusia. Kuswanto (2019) menjelas bahwa android memiliki pengaruh terhadap proses pembelajaran biologi, Deadara (2017) menjelaskan bahwa terjadi peningkatan pemahaman materi sistem reproduksi manusia berbasis android. Selanjutnya kajian Suryaningsih dkk., (2020) tentang pengembangan media pembelajaran praktikum virtual berbasis android untuk meningkatkan berpikir kreatif siswa. Pengembangan media berbasis android memberikan nilai tambahan terhadap proses pembelajaran (Sadiman, 2012).

Motivasi serta berpikir kreatif menjadi poin penting dalam pengerjaan soal TTS sehingga dapat meningkatkan proses pembelajaran di kelas. Media permainan puzzle menurut Khairunnisa dkk, (2017) diprediksi memiliki pengaruh terhadap peningkatan pemahaman peserta didik saat belajar. Permainan 
crossword puzzles (TTS) disusun secara sistematis sehingga mudah dipahami dan merangsang siswa untuk berpikir kreatif dalam menjawab pertanyaan TTS, keadaan ini dapat memudahkan siswa untuk memperoleh pengetahuan (Ule et al., 2021).

Kelebihan penelitian pengembangan media pembelajaran TTS biologi materi sistem gerak pada manusia antara lain: a) Pengembangan media pembelajaran TTS berbasis android ini memiliki langkahlangkah yang diprediksi dapat meningkatkan kemampuan berpikir dan konsentrasi siswa; b) Media TTS biologi ini dapat dikerjakan secara individu ataupun kelompok; c) Penyajian media TTS biologi ini dilengkapi dengan Info biologi, gambar yang berkaitan dengan materi sistem gerak, dan petunjuk penggunaan media berbasis android; d) TTS biologi dikembangkan sesuai dengan kompetensi inti, kompetensi dasar, indikator pencapaian kompetensi yang sesuai dengan kurikulum 2013.

\section{SIMPULAN}

Berdasarkan hasil penelitian pengembangan media TTS biologi dapat disimpulkan bahwa Prosedur penelitian ini mengacu pada model pengembangan Borg and Gall yang dimodifikasi ke dalam Sembilan tahapan meliputi potensi masalah, pengumpulan data, desain produk, uji coba produk tahap I, revisi produk tahap I, uji coba produk tahap II, revisi produk tahap II, Uji coba produk tahap III, revisi dan penyempurnaan produk. Pengembangan media teka-teki silang pada materi sistem gerak pada manusia berbasis android untuk memberdayakan keterampilan berpikir kreatif siswa di SMA Negeri Wolojita, hasil Validasi para validator menyimpulkan bahwa meida TTS sangat valid untuk diimplementasikan selanjutnya dilakukan uji coba produk I, II dan II menghasilkan kesepakatan bahwa Media TTS sangat layak untuk digunakan dalam pembelajaran Biologi khusus materi sistem gerak dalam meningkatkan berpikir kreatif siswa.

\section{Daftar Pustaka}

Ade, M. Y. N., Bare, Y., \& Mago, O. Y. T. (2021). Pengembangan Media Pembelajaran Teka-Teki Silang (TTS) Pada Materi Sistem Gerak Untuk Kelas XI SMA. JURNAL PENDIDIKAN MIPA, 11(2), 63-75. https://doi.org/10.37630/jpm.v11i2.485

Bare, Y., Putra, S. H. J., Bunga, Y. N., Mago, O. Y. T., S, M., \& Boli, Y. T. (2021). Implementasi Biology Club I di SMA Karitas Watuneso, Kecamatan Lio Timur, Kabupaten Ende. Jurnal UDINUS: Jurnal Pengabdian Nusantara, 4(2), 321-328. https://doi.org/10.29407/ja.v4i2.15286

Bare, Y., \& Sari, D. R. T. (2021). Pengembangan Lembar Kerja Mahasiswa (LKM) Berbasis Inkuiri Pada Materi Interaksi Molekuler. BioEdUIN, 11(1), 8. https://doi.org/10.15575/bioeduin.v11i1.12077

Borg, W. R., \& Gall, M. D. (2003). Educational Research: An Introduction. London : Longman Inc.

Dawa, R. S., Bunga, Y. N., \& Bare, Y. (2021). Pengembangan LKPD Berbasis Inkuiri Terbimbing Pada Materi Sistem Pencernaan di SMAS Katolik St. Gabriel. Jurnal Ilmiah Wahana Pendidikan, 7(8). https://doi.org/10.5281/ZENODO.5781429

Deadara, E. (2017). Pengembangan Media Pembelajaran Sistem Reproduksi Manusia Berbasis Android Untuk Meningkatkan Pemahaman Konsep Peserta Didik. Jurnal Prodi Pendidikan Biologi, 6, 13.

Elci, T. N., Bare, Y., \& Mago, O. Y. T. (2021). Pengembangan Media Pembelajaran Biologi Berbasis Android Menggunakan Model Pembelajaran Problem Based Learning Pada Materi Sistem Ekskresi Di Kelas VIII SMP. JURNAL PENDIDIKAN MIPA, 11(2), 54-62. https://doi.org/10.37630/jpm.v11i2.484

Fourwantono, F. A. (2017). Pengembangan Media Teka-Teki Silang Biologi Untuk Memberdayakan Keterampilan Berpikir Kreatif Peserta Didik SMP Negeri 9 Bandar Lampung. Universitas Islam Raden Intan.

Kuswanto, J. (2019). Pengembangan Media Pembelajaran Berbasis Android Pada Mata Pelajaran Biologi Kelas XI. Indonesian Journal of Business Intelligence (IJUBI), 2(2), 65. https://doi.org/10.21927/ijubi.v2i2.1139

Pada, K., Bare, Y., \& Putra, S. H. J. (2021). Pengembangan Lembar Kerja Peserta Didik (LKPD) Biologi Berbasis Pendekatan Scientific Materi Sistem Ekskresi Pada Manusia Kelas VIII SMP Negeri 2 
$\begin{array}{lllll}\text { Maumere. Jurnal } & \text { Ilmiah }\end{array}$ https://doi.org/10.5281/ZENODO.5769603

S, M., \& Bare, Y. (2019). Meningkatkan Hasil Belajar Siswa pada Konsep Perubahan dan Pelestarian Lingkungan Hidup dengan Model Discovery Learning di SMAS Katolik ST Gabriel Maumere. BIOEDU SCIENCE: Jurnal Pendidikan Biologi dan Sains, 3(2), 84-89. https://doi.org/10.29405/j.bes/3284-893298

Sadiman, A. (2012). Media Pendidikan (1st ed.). Jakarta : PT. RajaGrafindo Persada.

Sizi, Y., Bare, Y., \& Galis, R. (2021). Pengaruh Model Pembelajaran Kooperatif Tipe Talking Stick Terhadap Keaktifan dan Hasil Belajar Kognitif Peserta Didik SMP Kelas VIII. Spizaetus: Jurnal Biologi dan Pendidikan Biologi, 2(1), 8.

Suryaningsih, Y., Gaffar, A. A., \& Sugandi, M. K. (2020). Pengembangan Media Pembelajaran Praktikum Virtual Berbasis Android Untuk Meningkatkan Berpikir Kreatif Siswa. Bio Education: (The Journal of Science and Biology Education), 5(1). https://doi.org/10.31949/be.v5i1.2243

Ule, K. N., Bunga, Y. N., \& Bare, Y. (2021). Pengembangan Modul Pembelajaran Biologi Berbasis Jelajah Alam Sekitar (JAS) Materi Ekosistem Taman Nasional Kelimutu (TNK) SMA Kelas X. Dilabio: Jurnal Pendidikan dan Pembelajaran Biologi, 5(2), 10. https://doi.org/10.33369/diklabio.5.2.147-156

Wulan, N. P. J. D., Sumatra, I. I. W., \& Jampel, I. N. (2019). Pengembangan Media Permainan Edukatif TekaTeki Silang Berorientasi Pendidikan Karakter Pada Mata pelajaran IPS. Jurnal EDUTECH Universitas Pendidikan Ganesha, 7(1). http://dx.doi.org/10.23887/jeu.v7i1.20009 